\title{
Assessment of diet quality, nutrient intake, and dietary behaviours in obese children compared to healthy children
}

Ocena jakości diety, spożycia składników odżywczych i zachowań żywieniowych u dzieci otyłych w porównaniu z dziećmi zdrowymi

\author{
${ }^{1}$ Agnieszka Kozioł-Kozakowska, ${ }^{1}$ Martyna Kozłowska, ${ }^{2}$ Paweł J. Jagielski
}

\author{
${ }^{1}$ Department of Pediatrics, Gastroenterology and Nutrition, Jagiellonian University Medical College, \\ Krakow, Poland \\ ${ }^{2}$ Department of Nutrition and Drug Research, Jagiellonian University Medical College, Institute of Public \\ Health, Poland
}

\begin{abstract}
Introduction: Obesity has been recognised by the World Health Organisation as the most common chronic disease in the world. An increase in the prevalence of childhood obesity has been seen in Poland.

Purpose: The aim of this study was to compare the dietary behaviours, quality of diet, and nutrient intake in a group of obese children compared to children with normal body weight.

Material and methods: A total of 105 children aged between seven and 15 years were surveyed. The test group consisted of 52 obese patients from a Dietary Clinic in the Children's University Hospital in Cracow, without accompanying chronic diseases, and 53 normal weight patients. Children's nutritional behaviours and diet were assessed with a questionnaire (FFQ) and a 24-hour recall. To assess diet quality the Healthy Eating Indicator (HDI) was used.

Results: The diet of the studied obese children was rich in highly processed and high-fat products, and poor in vegetables, fruits, and wholegrain products. Obese children consumed on average $73.42 \pm 19.60 \mathrm{kcal}$ per body weight whereas normal-weight children consumed $49.89 \pm 12.20(p<0.01)$ and obtained more energy from fat than from carbohydrates. A low intake of vitamins A and D, folic acid, calcium, iodine, and iron in both groups was observed. The HDI showed a low-quality diet in nearly $40 \%$ of obese children. Conclusions: Dietary treatment of obese children should concentrate not only on reduction of calories from food products but also on choices of high-nutrient-density products and on developing healthy eating habits.
\end{abstract}

Key words:

children and adolescents, obesity; diet quality, nutrition behaviours.

\section{Streszczenie}

Wprowadzenie: Otyłość została uznana przez Światową Organizację Zdrowia za najczęstszą przewlekłą chorobę na świecie. W Polsce obserwuje się wzrost rozpowszechnienia otyłości wśród dzieci.

Cel pracy: Porównanie jakości diety, spożycia składników odżywczych oraz zachowań żywieniowych w grupie otyłych dzieci w porównaniu z dziećmi o prawidłowej masie ciała.

Materiał i metody: Badaniami objęto 105 dzieci w wieku 7-15 lat. Grupę badaną stanowiło 52 otyłych pacjentów z Poradni Dietetycznej Uniwersyteckiego Szpitala Dziecięcego w Krakowie bez towarzyszących chorób przewlekłych oraz 53 pacjentów z prawidłową masą ciała. Zachowania żywieniowe dzieci i ich dietę oceniono za pomocą kwestionariusza (FFQ) oraz 24-godzinnego wywiadu żywieniowego. Do oceny jakości diety wykorzystano wskaźnik Healthy Diet Indicator (HDI).

Wyniki: Dieta badanych otyłych dzieci była bogata w wysoko przetworzone i wysokotłuszczowe produkty oraz uboga w warzywa, owoce i produkty pełnoziarniste. Otyłe dzieci spożywały średnio 73,42 $\pm 19,60 \mathrm{kcal} / \mathrm{kg}$ m.c. vs 49,89 $\pm 12,20 \mathrm{kcal} / \mathrm{kg} \mathrm{m} . c$. (p < 0,01) dzieci o prawidłowej masie ciała oraz więcej energii z tłuszczów niż z węglowodanów. Zaobserwowano niskie spożycie witaminy A, D, kwasu foliowego, wapnia, jodu i żelaza w obu grupach. Za pomocą HDI wykazano niską jakość diety u prawie $40 \%$ otyłych dzieci. Wnioski: Leczenie dietetyczne otyłych dzieci powinno koncentrować się nie tylko na zmniejszeniu kalorii pochodzących z produktów spożywczych, lecz także na wyborze produktów o dużej gęstości odżywczej oraz nauce zdrowych nawyków żywieniowych.

Słowa kluczowe:

dzieci i młodzież, otyłość, jakość diety, zachowania żywieniowe. 


\section{Introduction}

Obesity has been recognised by the World Health Organisation as the most common chronic disease in the world and is known as the epidemic of the $21^{\text {st }}$ century. In just the last three decades, the proportion of obese people has doubled, and forecasts indicate further growth [1]. The problem of excess weight, according to WHO data from 2016, concerned about 41 million children under five years of age in the world, and it is estimated that the number will rise to 70 million by 2025 [2]. According to a PITNUTS study, overweight concerned $14.5 \%$ and obesity $13 \%$ of Polish children aged 13 to 36 months [3]. Almost onethird $(30.7 \%)$ of eight-year-old children examined by the Childhood Obesity Surveillance Initiative (COSI) had excessive body mass [4]. In contrast, data from the Health Behaviour in Schoolaged Children (HBSC) study indicate that the proportion of adolescents aged 11 to 15 years with abnormal body mass in Poland was $21.3 \%$ (16.6\% for overweight and $4.7 \%$ for obesity, respectively) [5]. Obesity in children leads to many health consequences such as dyslipidaemia, hypertension, insulin resistance or impaired glucose metabolism, non-alcoholic fatty liver disease, increased risk of non-communicable diseases such as type 2 diabetes, and cardiovascular disease. Unfortunately, excessive body weight is often underestimated by parents, perceived as a temporary problem that the child will grow out of; however, about $55 \%$ of children with excessive body weight in preschool age will become obese teenagers. The prevalence of obesity between 15 and 17 years of age is associated with a 17.5-fold higher risk of obesity in adulthood [6]. Obesity is the consequence of a chronic imbalance between energy intake and energy expenditure, which is a result of incorrect diet and inadequate physical activity.

\section{Aim of the study}

The aim of this study was to compare dietary behaviours, the quality of diet, and the implementation of nutritional standards in a group of obese children compared to children with normal body weight.

\section{Material and methods}

Participation in the study was voluntary and anonymous. Informed consent was signed by parents or legal caregivers of children. This study was reported according to the Strengthening the Reporting of Observational Studies in Nutritional Epidemiology (STROBE-nut) checklist [7]. The study was conducted according to the ethical principles for medical research stated in the Helsinki Declaration and was approved by the authors' Institutional Review Board [8]. The study was carried out between December 2018 and February 2019.

A total of 105 children aged between seven and 15 years were surveyed. The studied group consisted of 52 patients from a Dietary Clinic in the Children's University Hospital in Cracow, with obesity but without metabolic complications of obesity (hypertension or diabetes mellitus) except for abnormal lipid values, based on the information contained in the medical card. The control group was chosen in terms of gender and age. The group consisted of 53 patients with normal weight, recruited from the Primary Health Care Clinic. Inclusion criteria for the study were the absence of chronic diseases and, in the case of obesity group - BMI value above the $95^{\text {th }}$ percentile, and in the case of the control group - BMI between the $10^{\text {th }}$ and $85^{\text {th }}$ percentile. The $\mathrm{BMI}$ value was calculated (according to the formula body mass $[\mathrm{kg}] /$ height $\left.\left[\mathrm{m}^{2}\right]\right)$ for adolescents under 18 years of age following the OLAF project (growth references for Polish school-aged children and adolescents); values exceeding the $95^{\text {th }}$ percentile were classified as obesity, and values between the $85^{\text {th }}$ and $95^{\text {th }}$ percentiles were classified as overweight [9]. Body weight and height were obtained from medical cards.

\section{Dietary assessment}

Children's nutritional behaviours and diet were assessed with a questionnaire and a 24-hour recall, which included a detailed description of the foods and beverages consumed, their amounts (portion size), brand (if relevant), and preparation (e.g. cooking method, addition of fat, recipe, ingredients, etc.). The interview was conducted by a qualified dietician by using a photo album of all food products. Parents of children also filled in a nutrition questionnaire, which concerned the following: food and beverage consumption frequency; number and frequency of meals; snacking in-between meals; regularity of meals; consumption of fast-foods; and use of dietary supplements. The Food Frequency Questionnaire-FFQ (70 items), which was used to capture habitual dietary intake, was similar to the validated Polish Questionnaire prepared by the Behavioural Conditions of Nutrition Team, Committee of Human Nutrition Science, Polish Academy of Science [10]. The frequency of consumption was determined in relation to the day, week, or month. The survey did not include open-ended questions. For the assessment of the frequency of consumption of selected products, food, and beverages, a seven-point scale was used. In the rest, the responses were assigned integer values, using selected scales, e.g. a twopoint scale ( $1=$ no, 2 = yes). Diet quality was also examined using the Healthy Diet Indicator (HDI). The HDI was categorised into low, intermediate, and high (0-2, 3, 4-7, respectively) [11]. This score includes six nutrients (saturated fatty acids, polyunsaturated fatty acids, cholesterol, protein, dietary fibre, and free sugars) and one food group (fruits and vegetables). Intake within the recommended range was assigned a score of 1 . The final $\mathrm{HDI}$ score was the sum of all components, ranging from 0 (minimal adherence) to 7 (maximal adherence).

\section{Data analysis}

A Dietetyk-Pro calculator was used to evaluate the implementation of nutrition standards. The Software used for the nutrient analysis of the food records included the Polish National Institute of Food and Food Science database. Dietary supplements were not included in the nutrient calculations. The values of macro and micronutrients were referred to the Polish norms according to the age and sex of the child. To evaluate the prevalence of 
nutrient adequacy the Estimated Average Requirement (EAR) or Adequate Intake (Al) was used. All the collected data were analysed statistically with the use of the PS IMAGO PRO 5 (IBM SPSS Statistics 25). Chi-square test or U Mann-Whitney test was used to compare the differences in the studied groups, assuming in a significance level of $\alpha<0.05$.

\section{Results}

A total of 105 children aged $7-15$ years were recruited, and the average age of children was 11.83 years $(S D=2.61)$. The group of obese children consisted of 52 children (49.5\%), and the control group comprised 53 children (50.5\%). Due to the selection of the control group relative to the gender, the distribution of this variable was equal in both groups. Anthropometric data are defined in Table I, while socio-economic and family characteristics of the participants with reference to the analysed groups (Obesity and Control) are presented in Table II.

The children who took part in the research differed in the frequency of consumption of all food products analysed, except for groats, poultry meat, fish, and cheese, in respect of which no significant differences in the frequency of intake were observed. The greatest differences in the frequency of consumption were observed in the range of dietary products such as whole grains, natural dairy products, vegetables and fruits, legumes, milk and natural dairy products, and oils, which were consumed significantly less frequently in the group of obese children (Table III). In the group of obese children one out of three consumed different types of sweets daily (32.5\% vs. $15.25 \%, p<0.05)$. The differences were also evident in the amount of fluid intake: one out of three of obese children drank fruit nectars and sweetened beverages daily (once a day or several times a day). Flavoured water was consumed daily by $23 \%$ of obese children. With regard to the fluids consumed by obese children, tea sweetened with sugar was the predominating drink (Table III).

A higher incidence of incorrect eating behaviours was observed in the obesity group. A significantly smaller proportion

Table I. Anthropometric parameters of the studied groups

\begin{tabular}{llllll}
\hline & \multicolumn{2}{c}{ Normal weight } & \multicolumn{2}{l}{ Obesity } & \multirow{2}{*}{ p value } \\
\cline { 2 - 5 } & $\mathrm{X}$ & $\mathrm{SD}$ & $\mathrm{x}$ & $\mathrm{SD}$ & \\
\hline Age [years] & 11.8 & 2.6 & 11.8 & 2.6 & $\mathrm{NS}$ \\
\hline Height [cm] & 153.2 & 16.2 & 154.0 & 15.9 & $\mathrm{NS}$ \\
\hline Weight $[\mathrm{kg}]$ & 42.8 & 11.6 & 78.7 & 20.8 & $<0.01$ \\
\hline BMI $\left[\mathrm{kg} / \mathrm{m}^{2}\right]$ & 17.8 & 1.5 & 32.6 & 3.3 & $<0.01$ \\
\hline
\end{tabular}

$\mathrm{X}$ - mean; SD - standard deviation; $p$ - Mann-Whitney U test value; NS - not significant of obese children compared to children from control group ate breakfast every day (57.0\% vs. $79.2 \%, p<0.01$ ); a duplicate main dish was consumed daily by $15.3 \%$ of obese children and by $7.7 \%$ of children from the control group ( $p<0.01$ ). Fast food products were consumed several times a month by $59.6 \%$ of obese children and by $26.4 \%$ of children with normal weight $(p<0.01)$. It was also observed that obese children statistically significantly more often than children with normal weight bought candy bars (44.23\% vs. $18.87 \%, p<0.01$ ), buns and donuts $(48.08 \%$ vs. $22.64 \%, p<0.01$ ), and biscuits and wafers (34.62\% vs. $16.98 \%$, $p<0.01)$ in school shops every day. In contrast, there was an inverse situation in the case of fruit: children with normal body weight bought fruit at school shops statistically significantly more often than obese children (20.75\% vs. 3.85\%, $p<0.01)$ (Table IV).

Table II. Socio-economic and family characteristics in total and with reference to studied groups

\begin{tabular}{|c|c|c|c|c|c|}
\hline & \multicolumn{2}{|c|}{$\begin{array}{l}\text { Normal } \\
\text { weight }\end{array}$} & \multicolumn{2}{|c|}{ Obesity } & \multirow[t]{2}{*}{$p$ value } \\
\hline & $x$ & SD & $x$ & SD & \\
\hline \multicolumn{5}{|l|}{ Sex } & \multirow{3}{*}{ NS } \\
\hline Girls & 21 & 39.6 & 20 & 38.5 & \\
\hline Boys & 32 & 60.4 & 32 & 6.5 & \\
\hline
\end{tabular}

\begin{tabular}{lllll}
\hline Place of residence & & & & \\
\hline Village & 18 & 34.0 & 35 & 67.3 \\
\hline Small town * & 11 & 20.8 & 6 & 11.5 \\
\hline Big town** & 24 & 45.3 & 11 & 21.2
\end{tabular}

\begin{tabular}{ccccc}
\hline Mother's education level & & & & \\
\cline { 1 - 5 } Primary & 8 & 15.1 & 4 & 7.7 \\
\hline Vocational & 10 & 18.9 & 17 & 32.7 \\
\cline { 1 - 4 } Secondary & 12 & 22.6 & 14 & 26.9 \\
\hline Higher & 23 & 43.4 & 17 & 32.7 \\
\hline
\end{tabular}

Father's education level

\begin{tabular}{lllll}
\hline Primary & 7 & 13.2 & 4 & 7.7 \\
\cline { 1 - 4 } Vocational & 13 & 24.5 & 25 & 48.1 \\
\cline { 1 - 4 } Secondary & 18 & 34.0 & 15 & 28.8 \\
\hline Higher & 15 & 28.3 & 8 & 15.4 \\
\hline
\end{tabular}

* more than 50-100 thousand inhabitants

** more than 100 thousand inhabitants

$\mathrm{N}$ - number; $\mathrm{p}-2$ test value; NS - not significant 


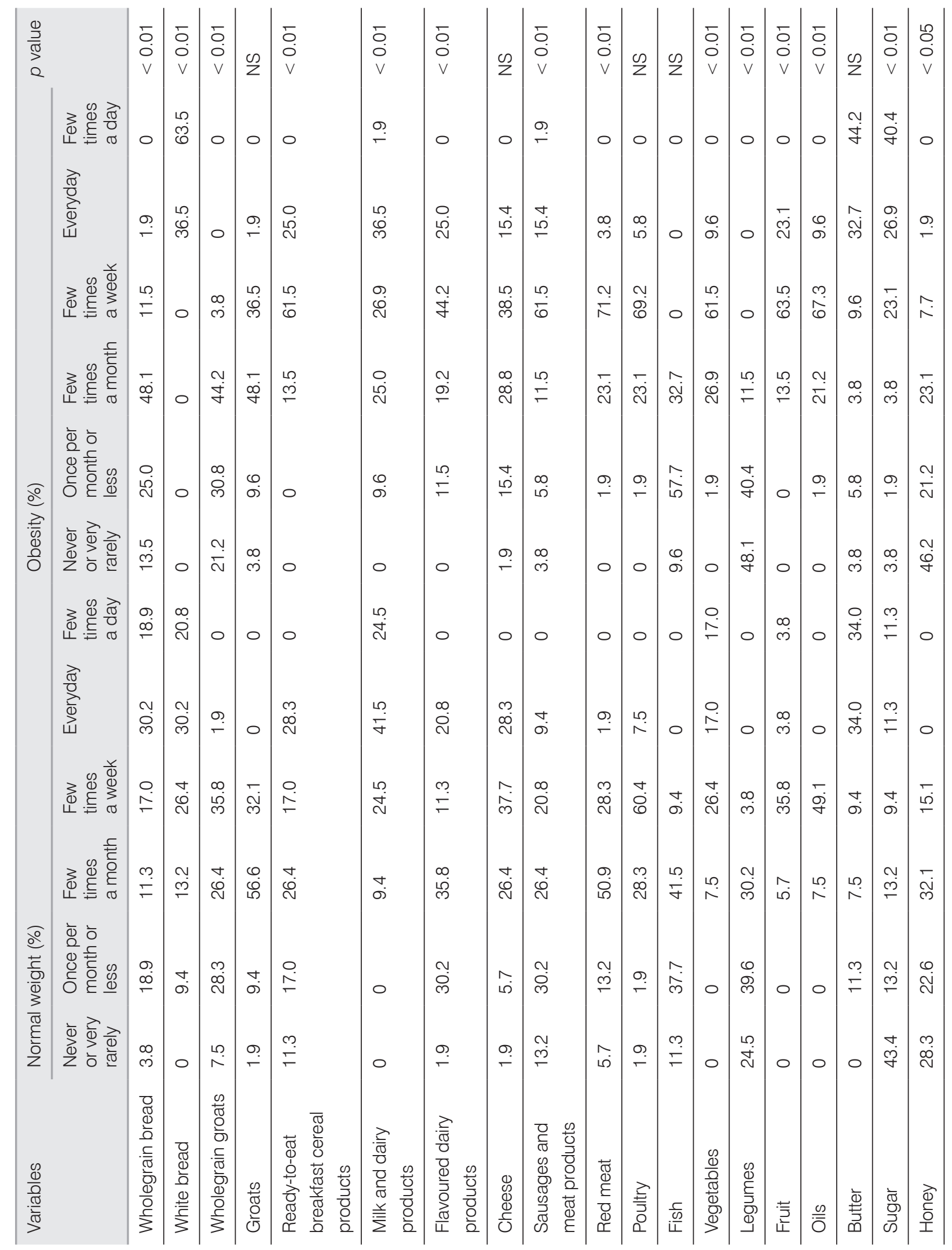




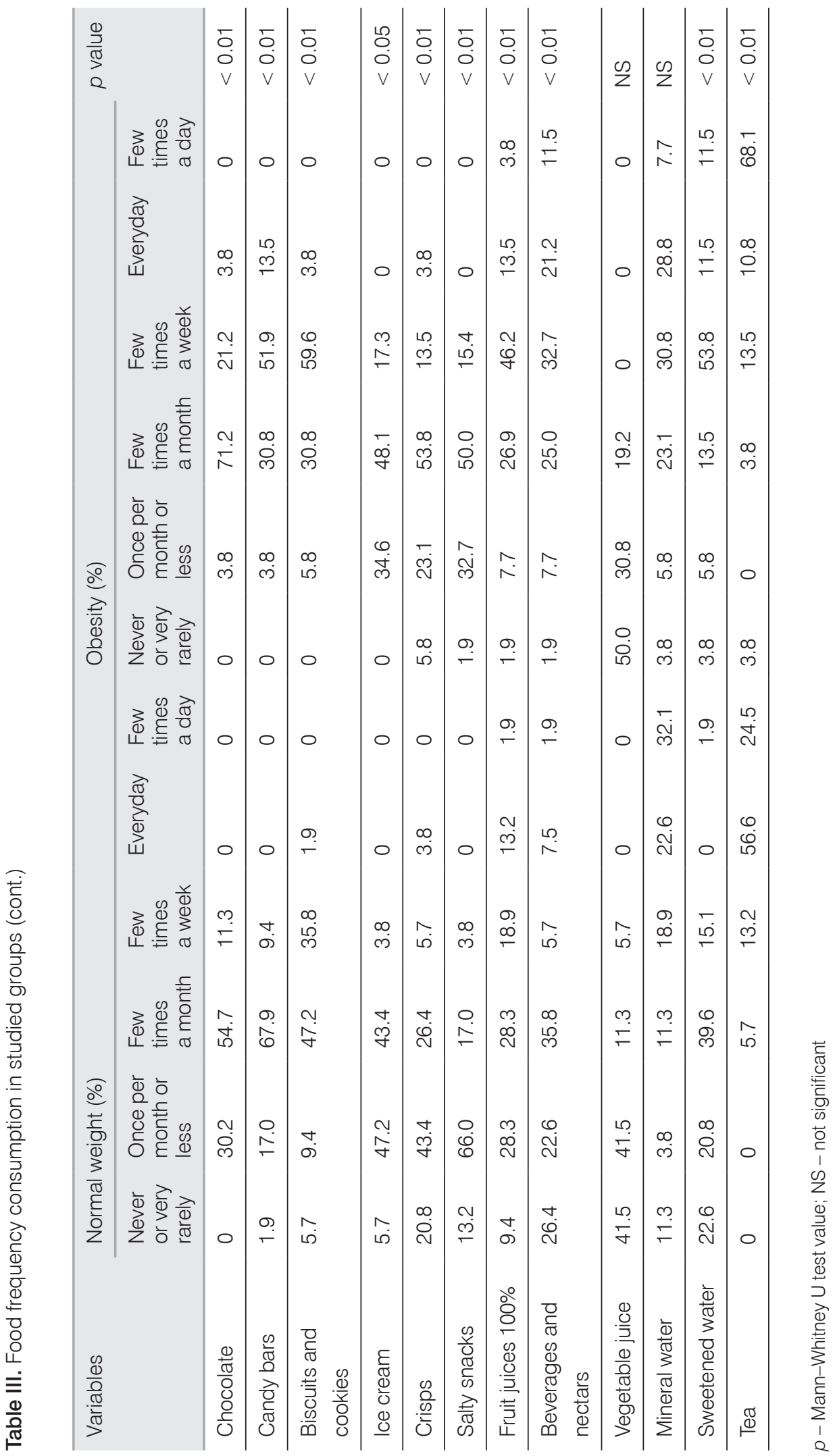




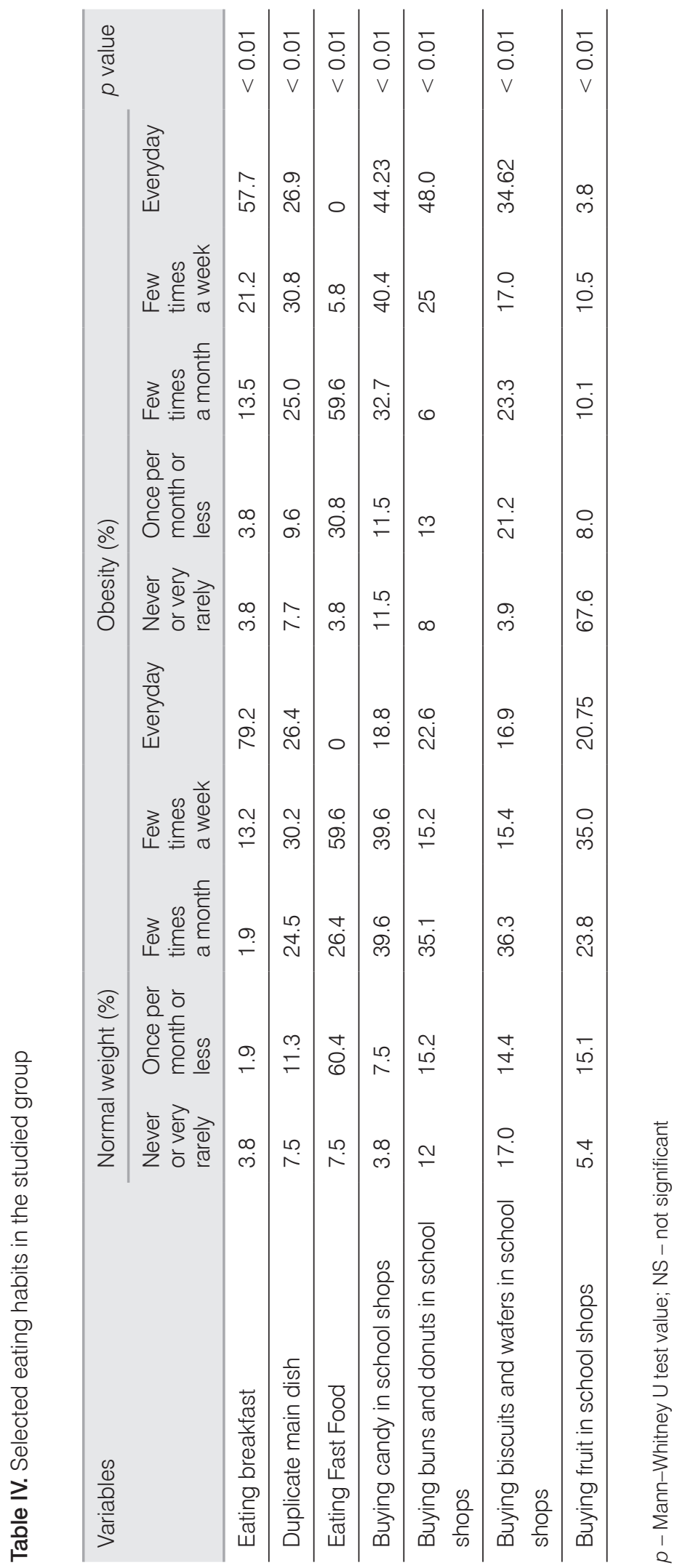

The analysis of the research group in reference to macronutrients showed significant differences in the implementation of dietary standards. Obese children consumed on average $73.42 \pm 19.60 \mathrm{kcal}$ per body weight (3171 $\pm 876 \mathrm{kcal}$ per day) whereas normal-weight children consumed $49.89 \pm 12.25 \mathrm{kcal}$ per body weight (2087 $\pm 373 \mathrm{kcal}$ per day), $p<0.01$. The macronutrient composition of the obese children's diet differed from the normal-weight children's diet by its increased proportions of all macronutrients and the percentage content of energy. Obese children consumed more energy from fat than from carbohydrates - the intake of saturated (SFA) and monounsaturated (MUFA) fat was twice as high as for children from the control group. What it more, in the case of obese children, significantly higher consumption of cholesterol as well as polyunsaturated fatty acids (PUFA) was observed. Carbohydrate intake was also greater in the group of obese children, who consumed on average $150 \mathrm{~g}$ more carbohydrates than children with normal body weight, and almost half more sucrose and significantly less dietary fibre (Table V).

Most micronutrient intakes were adequate when compared with the recommendations; the exceptions were low intakes of calcium, iodine, and iron. In both groups, an overdose of the recommended sodium intake was observed; however, in the group of obese children, sodium intake was half higher than that of the nutrition standards (Table VI). When comparing food intake of vitamins between both groups, it was observed that obese children obtained from their diet statisticalIy significantly less vitamin A and folic acid than their healthy peers. Regardless of the group, the children's consumption of vitamin $\mathrm{D}$ did not meet the requirements of the recommended daily intake of this vitamin. The calculated HDI indicated that nearly $40 \%$ of obese children and $17 \%$ of children from the control group had poor quality diets (Fig. 1).

\section{Discussion}

The aim of this study was to compare dietary behaviours, diet quality, and daily intake level of nutrients in the groups of obese children and those with normal weight. The results of the study show a number of nutritional errors among obese children that lower the quality of their diet and affect the further accumulation of body fat.

First of all, obese children consumed too much energy in relation to their proper weight. The differences between the group of obese and children with normal weight amounted an average of $1000 \mathrm{kcal}$, which is $30 \%$ more calories than they required, taking into consideration their proper weight age and gender. The results of other studies also show an excess of energy in the diets of obese children [12-14]. The analysis of the individual components being the source of the energy excess in 
Table V. Daily dietary intake of energy, macronutrients, and fibre in the studied groups. Values are mean and standard deviation X (SD)

\begin{tabular}{|c|c|c|c|c|}
\hline & Normal Weight & Obesity & $p$ value & Recommended Intake \\
\hline \multicolumn{5}{|l|}{ Energy } \\
\hline kcal/day & 2087.51 (373.71) & 3171.33 (876.35) & \multirow[t]{2}{*}{$<0.01$} & \multirow{2}{*}{$\begin{array}{l}1800-2450 \mathrm{kcal} / \text { day depending on } \\
\text { weight, age, and sex ( } 7-15 \text { year) }\end{array}$} \\
\hline kg/body weight & $49.89(12.25)$ & $73.42(19.60)$ & & \\
\hline \multicolumn{5}{|l|}{ Protein } \\
\hline g/day & $78.6(18.7)$ & $99.6(33.9)$ & $<0.01$ & \multirow[t]{2}{*}{ 10-20\% energy } \\
\hline \% energy & $15.10(2.3)$ & $16.20(4.7)$ & $<0.01$ & \\
\hline \multicolumn{5}{|l|}{ Carbohydrates } \\
\hline g/day & $308.7(61.5)$ & $453.30(127.8)$ & $<0.01$ & \multirow[t]{2}{*}{$55-60 \%$ energy } \\
\hline \% energy & $59.1(4.6)$ & $57.59(6.20)$ & $<0.01$ & \\
\hline \multicolumn{5}{|l|}{ Sucrose } \\
\hline g/day & $27.27(14.18)$ & $50.46(29.48)$ & $<0.01$ & NA \\
\hline \multicolumn{5}{|l|}{ Protein } \\
\hline g/day & $78.6(18.7)$ & $99.6(33.9)$ & $<0.01$ & \multirow[t]{2}{*}{ 10-20\% energy } \\
\hline \% energy & $29.20(3.8)$ & $41.60(14.1)$ & $<0.01$ & \\
\hline \multicolumn{5}{|l|}{ Saturated } \\
\hline g/day & $25.40(8.48)$ & $44.06(23.25)$ & $<0.01$ & \multirow[t]{2}{*}{$<10 \%$ energy } \\
\hline \% energy & $11.70(3.33)$ & $15.99(7.32)$ & $<0.01$ & \\
\hline \multicolumn{5}{|l|}{ Monounsaturated } \\
\hline g/day & 26.88 (6.53) & $46.59(27.01)$ & $<0.01$ & \multirow[t]{2}{*}{$<15 \%$ energy } \\
\hline \% energy & $11.65(2.21)$ & $16.85(8.89)$ & & \\
\hline \multicolumn{5}{|l|}{ Polyunsaturated } \\
\hline g/day & $11.15(5.24)$ & $15.27(8.94)$ & $<0.01$ & \multirow[t]{2}{*}{$<10 \%$ energy } \\
\hline \% energy & $4.81(2.05)$ & $5.63(3.34)$ & & \\
\hline \multicolumn{5}{|l|}{ Cholesterol } \\
\hline mg/day & $261.98(137.14)$ & 370.91 (17.58) & $<0.01$ & $<300$ mg/day \\
\hline \multicolumn{5}{|l|}{ Fibre } \\
\hline g/day & $23.27(8.34)$ & $17.95(9.3)$ & $<0.01$ & $0.5 \mathrm{~g} / \mathrm{kg}$ body weight $/$ day \\
\hline
\end{tabular}

$X$ - mean; SD - standard deviation; $\mathrm{p}$ - Mann-Whitney U test value; NS - not significant 
Table VI. Selected eating habits in the studied group

\begin{tabular}{|c|c|c|c|c|c|c|c|c|c|c|}
\hline \multirow[t]{3}{*}{ Variables } & \multicolumn{4}{|c|}{ Food intake } & \multirow[t]{3}{*}{$p$ value } & \multicolumn{4}{|l|}{$\% \mathrm{DRI}$} & \multirow[t]{3}{*}{$p$ value } \\
\hline & \multicolumn{2}{|c|}{ Normal weight } & \multicolumn{2}{|l|}{ Obesity } & & \multicolumn{2}{|c|}{ Normal weight } & \multicolumn{2}{|c|}{ Obesity } & \\
\hline & $x$ & $\mathrm{SD}$ & $x$ & SD & & $x$ & SD & $x$ & $\mathrm{SD}$ & \\
\hline Sodium (mg) & 1770.9 & 676.7 & 2316.0 & 1037.3 & $<0.01$ & 130.8 & 51.4 & 168.6 & 71.3 & $<0.01$ \\
\hline Potassium (mg) & 3264.3 & 979.6 & 3009.8 & 1242.7 & NS & 132.2 & 36.5 & 122.5 & 52.1 & NS \\
\hline Calcium (mg) & 633.7 & 314.6 & 526.6 & 255.5 & NS & 52.4 & 27.4 & 43.1 & 20.7 & NS \\
\hline Phosphorus (mg) & 1222.5 & 403.0 & 1156.3 & 415.0 & NS & 124.4 & 53.1 & 115.6 & 51.1 & NS \\
\hline Magnesium (mg) & 309.2 & 117.7 & 271.8 & 107.6 & NS & 128.0 & 63.9 & 110.5 & 61.9 & NS \\
\hline Iron (mg) & 10.8 & 3.5 & 10.4 & 3.5 & NS & 90.5 & 28.1 & 90.5 & 29.2 & NS \\
\hline Zinc (mg) & 9.0 & 2.7 & 9.1 & 3.4 & NS & 117.8 & 43.2 & 114.8 & 43.4 & NS \\
\hline Copper (mg) & 1.2 & 0.4 & 1.08 & 0.4 & $<0.05$ & 157.6 & 47.1 & 135.8 & 48.2 & $<0.05$ \\
\hline Manganese (mg) & 3.7 & 2.0 & 2.9 & 1.7 & $<0.05$ & 212.5 & 109.6 & 166.1 & 108.0 & $<0.01$ \\
\hline lodine $(\mu \mathrm{g})$ & 39.3 & 31.5 & 28.9 & 30.1 & $<0.05$ & 30.1 & 21.9 & 22.6 & 24.7 & $<0.01$ \\
\hline Vit. A $(\mu \mathrm{g})$ & 1312.9 & 818.8 & 919.9 & 582.9 & $<0.05$ & 203.1 & 131.7 & 139.5 & 92.6 & $<0.05$ \\
\hline Vit. D $(\mu \mathrm{g})$ & 2.8 & 3.8 & 3.0 & 3.4 & NS & 18.3 & 25.9 & 19.7 & 23.2 & NS \\
\hline Vit. E (mg) & 9.8 & 3.6 & 12.3 & 6.2 & NS & 116.2 & 42.4 & 141.5 & 74.2 & NS \\
\hline Vit. $B_{1}$ (mg) & 1.2 & 0.4 & 1.6 & 0.9 & NS & 114.0 & 36.9 & 147.0 & 86.5 & NS \\
\hline Vit. $B_{2}$ (mg) & 1.5 & 0.5 & 1.4 & 0.6 & NS & 143.6 & 45.4 & 136.9 & 54. & NS \\
\hline Vit. $B_{3}(\mathrm{mg})$ & 15.3 & 6.9 & 17.9 & 9.4 & NS & 113.6 & 51.3 & 130.9 & 64.8 & NS \\
\hline Vit. $B_{6}(\mathrm{mg})$ & 2.0 & 0.6 & 2.0 & 0.9 & NS & 174.6 & 54.0 & 175.4 & 80.9 & NS \\
\hline Folic acid $(\mu \mathrm{g})$ & 349.1 & 146.0 & 295.9 & 136.1 & $<0.05$ & 100.6 & 36.0 & 85.1 & 38.0 & $<0.05$ \\
\hline Vit. $B_{12}(m g)$ & 3.1 & 2.4 & 2.9 & 2.1 & NS & 152.1 & 104.8 & 140.8 & 114.8 & NS \\
\hline Vit. C (mg) & 135.3 & 87.0 & 132.3 & 135.3 & NS & 226.8 & 134.0 & 221.7 & 219.5 & NS \\
\hline
\end{tabular}

$X$ - mean; SD - standard deviation; $p$ - Mann-Whitney U test value; NS - not significant

obese children showed that fats are in first place, with carbohydrates in second. Obese children consumed an average of twice as much fat as did their peers with normal body weight, which is consistent with the results of other studies in the population of Polish children [12, 15]. What is interesting, also in the population of obese children from Spain it was observed that, respectively, $45 \%$ and $38 \%$ of the studied obese children had fat and carbohydrate intake levels above the norms (Acceptable Macronutrient Distribution Range-AMDR) [14]. Similar results were observed in overweight Greek children, who consumed less energy from carbohydrates and more from fat, ac- cording to AMDR [15-17]. Given the fact that fat is the most calorific nutrient ( $9 \mathrm{kcal}$ per $1 \mathrm{~g}$ ), it constitutes the main source of excess energy in the diet of children. The children differed statistically significantly not only in terms of the amount of delivered fat but also its type. Obese children consumed an average of almost twice as much saturated and monounsaturated fatty acids, which come mostly from sweets, salted snacks, and meat products, and which were eaten more frequently in the group of obese children than by children with normal body weight. Obese children had a diet with an average of $70 \mathrm{mg}$ of cholesterol more than their peers with normal weight. The 
results of another study show the negative effect on the lipid profile of excessive amounts of saturated fatty acids in the diet [18]. Advice to reduce saturated fat intake among children results in a significant reduction in total and LDL-cholesterol levels, as well as diastolic blood pressure, without adverse effects. The results of this review suggest that the greatest effect on blood cholesterol occurred when SFA was replaced with PUFA or a mixture of PUFA/MUF, which was found in the current $\mathrm{WHO}$ recommendations [19]. In our study group of obese children, excessive protein intake was observed; the standard for the body weight was exceeded by an average of $7 \%$, whereas the healthy children did not exceed the daily standard. As far as sugars are concerned, attention should be paid to the amount of sucrose consumed by the research group. Obese children consumed on average twice as much sucrose as the children with normal weight. Apart from using sugar to sweeten meals and drinks, another source of sucrose in the obese children's diet were sweets. These results coincide with the results of other Polish studies, which confirm the high intake of sucrose among obese children $[20,21]$. Another source of simple sugars in the diet of children was sweetened drinks and flavoured water. A meta-analysis of consumption of sweetened beverages in the paediatric population revealed that more than $80 \%$ of teenagers consume such drinks every day [22]. The results of other meta-analyses unanimously observe that excessive consumption of sweetened beverages increases the risk of overweight and obesity as well as tooth decay among children and may result in the development of insulin resistance [23, 24]. Such dependencies were not observed in case of $100 \%$ fruit juices. Concerns that $100 \%$ fruit juice may be associated with childhood weight gain or metabolic consequences have not been supported by most systematic reviews and meta-analyses [25]. Juice consumption in an isocaloric diet may be particularly important for its quality. Studies show that children who drink fruit juices also consume more fruit and vegetables, and their diet is of higher quality [26].

More than half $(57.7 \%)$ of children with obesity did not obtain the standard amount of fibre in their diet (Al), whereas in the group of children with normal weight the percentage was almost two times smaller (30.2\%). Similar results were observed in the group of obese children from Kozachstan [27]. Dietary fibre intake from vegetables, fruit, and whole cereal grains reduces the risk of obesity and enriches the diet with high-nutrient and low-energy products $[28,29]$. It has also been shown that there are many other benefits associated with the appropriate amount of dietary fibre in children's diets; for example, lower risk of developing cardiovascular diseases, hypertension, insulin resistance, and diabetes mellitus [30].

In both groups (study and control) children had a visible shortage of nutrients such as calcium, iron, and iodine. This confirms the fact that obese children's diet does not translate into a higher quality diet. Obese children, because of their excessive body mass, have a greater need for some nutrients, which in the case of a low-quality diet can lead to nutritional deficiencies. The main source of calcium in the diet are dairy products. Data from the 24-h interviews suggest that obese

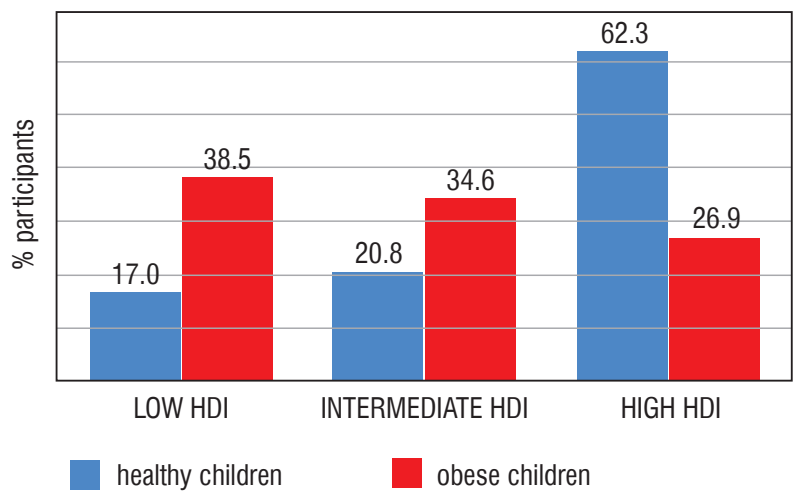

Figure 1. Healthy Diet Indicator (HDI) in studied groups

children consumed similar quantities of dairy products as did children with normal body weight, but the types of chosen product were different. Obese children were significantly more likely to consume sweetened dairy products than natural ones. In one study, it was observed that flavoured milk consumers (children 10-11 years old) had a higher average intake of energy, fat, and carbohydrate but also protein and calcium, compared with non-consumers [31]. Sweetened dairy drinks provided an average of $150 \mathrm{kcal}$ extra energy intake per day, some studies provide evidence that overweight/obese children may benefit from avoiding flavoured milk drinks; however, generally data do not suggest that the consumption of dairy foods is positively associated with weight and body composition [32]. Moreover, a number of different plausible mechanisms by which dairy products may affect energy balance and consequently body weight have been suggested. The most frequently cited is the mechanism relating to the effects of intracellular ionised $\mathrm{Ca}$ on adipocyte metabolism [32]. Another study refers to specific components of dairy food, and mainly whey and casein proteins were associated with increased satiety through delayed gastric emptying and regulation of the concentration of plasma amino acid and gastrointestinal hormones such as cholecystokinin, peptide YY, and gastrin [33]. Given the above as well as the fact that dairy products are a good source of calcium, iodine, and vitamin $\mathrm{K}$ and $B_{12}$, with low intake of these constituents in paediatric populations, it appears that the elimination of these products from the diet can bring more damage than benefits. Another ingredient, the intake of which was lower than the recommended norm in the children's diet, was iron. A number of studies show that obese children have, despite of lower iron intake, higher levels of serum ferritin; however, high levels of serum ferrite may not reflect increased iron stores but rather inflammation, that is way obese children and adolescents are exposed to iron deficiency $[34,35]$. Despite iodine playing a key role in psychomotor growth during puberty, its deficiency is common in the general Polish paediatric population [36]. Obese children consumed a diet containing statistically significantly more sodium than that of their peers with normal weight. The results concerning 
excessive consumption of salt coincide with the results of other Polish and foreign authors $[37,38]$. Excessive intake of sodium results from using too much salt, but also from high consumption of highly processed foods rich in sodium, such as chips, crisps, and other salty snacks, as well as bread. High sodium intake increases the risk of hypertension, which itself is already a complication of obesity [39]. The WHO recommends that people consume less than $5 \mathrm{~g}$ of salt ( $2 \mathrm{~g}$ of sodium) per day, to keep blood pressure at normal levels [40].

Vitamin $A$ is a fat-soluble vitamin that originates from plants as provitamin A carotenoids or from animals as retinol. In order to determine the intake of vitamin $A$, it takes into account the amount of ingested retinol as well as this vitamin formed from the carotenoids and expressed in the form of retinol equivalent (RE). In the study group the level of vitamin A (RE) intake was higher than the reference value. A higher level of vitamin A was observed in group normal-weight children than in the group of obese children, which might be a result of lower intake of fruit and vegetables in obese children. Concentrations of serum retinol were positively associated with BMI, visceral fat mass, and total body fat mass, whereas the opposite was found for serum $\alpha$-carotene, trans- $\beta$-carotene, and cis- $\beta$-carotene. In one study, higher retinol quartile was associated with a 2- to 3-fold greater probability of overweight and obesity, and the highest quartile of carotenoids was associated with reduced probability of obesity [41]. Low consumption of vegetables and fruit also translates into low levels of folic acid in the group of obese children. As expected, in our study, children from both groups had a low intake of a vitamin $D$ in their diet. Deficits of this vitamin are very common, and the recommendations of major scientific organisations including the Polish Society of Paediatric Endocrinology and Diabetes unanimously recommend vitamin $D$ supplementation for children and adolescents aged $1-18$ years in the amount of $600 \mathrm{UI}$ per day, and in obese children $1000 \mathrm{UI}$ or more, depending on the concentration of this vitamin in serum [42]. Not only the wrong choice of products but also portion size and bad eating habits, such as skipping breakfast and

\section{References}

1. Bluher M. Obesity: global epidemiology and pathogenesis. Nat Rev Endocrinol 2019; 15: 288-298.

2. Lobstein T, Jackson-Leach R, Moodie ML, et al. Child and adolescent obesity: part of a bigger picture. Lancet 2015; 385: 25102025. doi: 10.1016/S0140-6736(14)61746-3.

3. Weker H, Barańska M, Riahi A, et al. Dietary patterns in toddlers with excess weight. The 2016 PITNUTS study. Dev Period Med 2017; 21: 272-285.

4. http://www.euro.who.int/en/countries/poland/news/news/2017/06/ who-supports-poland-in-fighting-childhood-obesity; (accessed on 14 August 2019 r.)

5. Instytut Matki i Dziecka. Nadwaga i otyłość u polskich 8-latków w świetle uwarunkowań biologicznych, behawioralnych i społecz- eating irregular meals, influence the development of obesity, which was confirmed in our study as well as in the results of other authors [43-46]. In one systematic review in a group of over 300 thousand teenagers from 33 countries, it was shown that omitting breakfast concerns between 10 and $30 \%$ of young people, and this trend was growing with the age of the respondents. Omitting breakfast by girls was associated with a higher risk of obesity, worse lipid profile, higher arterial pressure, insulin resistance, and metabolic syndrome [46]. The HDI indicator, according to the assumptions, showed that obese children are more likely to have low-quality diets. Unfortunately, also a high proportion of healthy children presented low quality diets. HDI is associated with measures of children's weight status independently of energy density, physical activity, and other important covariates associated with obesity in children. This indicates that besides energy balance, dietary profiles may also contribute to the prevention of obesity in children [47].

Limitations of the study: The nutrition data were from only one 24-h recall, which may limit this study.

\section{Conclusions}

The diet of the studied obese children was rich in highly processed and high-fat products, and poor in vegetables, fruit, and wholegrain products, which fits into the definition of the Western-style diet [48]. In the diets of obese children an excess of energy intake mostly from fat was observed. Obese children were exposed to deficiencies of vitamin D, folic acid, iodine, iron, and calcium, which was a result of its low consumption or increased demand. Dietary treatment of obese children should concentrate not only on the reduction of calories from food products but also on choices of high-nutrient-density products rich in vitamins and minerals and on developing healthy eating behaviours. Nutritional education should also be directed to healthy children and their parents, as part of widespread prevention of obesity and its complications. nych. Raport z międzynarodowych badań WHO European Childhood Obesity Surveillance Initiative (COSI), Warszawa 2017.

6. Gawlik A, Zachurzok-Buczyńska A, Małecka-Tendera E. Powikłania otyłości u dzieci i młodzieży. Endokrynol Otył Zab Przem Mat 2009; 5 (1).

7. Lachat C, Hawwash D, Ocké MC, et al. Strengthening the reporting of observational studies in epidemiology-nutritional epidemiology (STROBE-nut): An extension of the STROBE statement. PLoS Med 2016; 13: e1002036. doi: 10.1371/journal.pmed.1002036

8. Puri KS, Suresh KR, Gogtay NJ, Thatte UM. Declaration of Helsinki, 2008: Implications for stakeholders in research. J Postgrad Med 2009; 55: 131-134. doi: 10.4103/0022-3859.52846

9. Kułaga Z, Litwin M, Tkaczyk M. Polish 2010 growth references for school-aged children and adolescents. Eur J Pediatr 2011; 170: 599-609. 
10. Jeżewska-Zychowicz M, Gawęcki J, Wądołowska L, et al. Beliefs and Eating Habits Questionnaire; Behavioral Conditions of Nutrition Team, Committee of Human Nutrition Science. Polish Academy of Sciences, Warszawa 2014; 3-20.

11. Heidi P, Beulens FJW, May AM, et al. Dietary patterns in relation to quality-adjusted life years in the EPIC-NL cohort. Prev Med 2015; 77: 119-124. doi: 10.1016/j.ypmed.2015.05.014

12. Falkowska A, Stefańska E, Ostrowska L, Ocena sposobu żywienia dzieci w wieku 10-12 lat o zróżnicowanym stopniu odżywienia. Endokrynol Otył Zab Przem Mat 2011; 7 (4).

13. Sharmanov TS, Salkhanova AB, Datkhabayeva GK. A comparative analysis of actual nutrition of children aged 9-10 years. Vopr Pitan 2018; 87: 28-41. doi: 10.24411/0042-8833-2018-10064

14. Ojeda-Rodríguez A, Zazpel, Morell-Azanza L, et al. Improved Diet Quality and Nutrient Adequacy in Children and Adolescents with Abdominal Obesity after a Lifestyle Intervention. Nutrients 2018; 10 : pii: E1500. doi: 10.3390/nu10101500

15. López-Sobaler AM, Aparicio A, González-Rodríguez LG, et al. Adequacy of usual vitamin and mineral intake in Spanish children and adolescents: ENALIA study. Nutrients 2017; 9: pii: E131. doi: 10.3390/nu9020131

16. López-Sobaler AM, Aparicio A, Rubio J, et al. Adequacy of usual macronutrient intake and macronutrient distribution in children and adolescents in Spain: A national dietary survey on the child and adolescent population, ENALIA 2013-2014. Eur J Nutr 2019; 58 : 705-719. doi: 10.1007/s00394-018-1676-3

17. Manios Y, Grammatikaki E, Papoutsou S, et al. Nutrient intakes of toddlers and preschoolers in Greece: The GENESIS Study. J Am Diet Assoc 2008; 108: 357-361. doi: 10.1016/j.jada.2007.10.042

18. Te Morenga L, Montez JM. Health effects of saturated and transfatty acid intake in children and adolescents: Systematic review and meta-analysis. PLoS One 2017; 12: e0186672. doi: 10.1371/ journal.pone.0186672

19. https://www.who.int/dietphysicalactivity/childhood_what_can_be_ done/en/; (accessed on 3 June 2019).

20. Kolarzyk E, Janik A, Kwiatkowski J. Ocena ryzyka zespołu metabolicznego u dzieci z nadwagą i otyłością. Część II. Żywieniowe czynniki ryzyka zespołu metabolicznego. Probl Hig Epidemiol 2011; 92: 747-752.

21. Dyląg H, Weker H, Barańska M, et al. Interwencja żywieniowa w grupie otyłych dzieci w wieku przedpokwitaniowym. Probl Hig Epidemiol 2011; 92: 569-572.

22. Dereń K, Weghuber D, Caroli M, et al. Consumption of SugarSweetened Beverages in Paediatric Age: A Position Paper of the European Academy of Paediatrics and the European Childhood Obesity Group. Ann Nutr Metab 2019; 74: 296-302. doi: https://doi. org/10.1159/000499828.

23. Bleich SN, Vercammen KA. The negative impact of sugar-sweetened beverages on children's health: an update of the literature. BMC Obesity 2018; 5: 6. doi: https://doi.org/10.1186/s40608-017-0178-9

24. Malik VS, Pan A, Willett WC, et al. Sugar-sweetened beverages and weight gain in children and adults: a systematic review and meta-analysis. Am J Clin Nutr 2013; 98: 1084-1102. doi: 10.3945/ ajcn.113.058362.

25. Murray RD. 100\% fruit juice in child and adolescent dietary patterns. Journal of the American College of Nutrition, 2019. doi: $10.1080 / 07315724.2019 .1615013$
26. O'Neil CE, Nicklas TA, Rampersaud GC, et al. One hundred percent orange juice consumption is associated with better diet quality, improved nutrient adequacy, and no increased risk for overweight/obesity in children. Nutr Res 2011; 31: 673-682. doi: 10.1016/j.nutres.2011.09.002

27. Sharmanov TS, Salkhanova AB, Datkhabayeva GK. A comparative analysis of actual nutrition of children aged 9-10 years. Vopr Pitan 2018; 87: 28-41. doi: 10.24411/0042-8833-2018-10064

28. Kranz S, Brauchla M, Slavin JL, et al. What Do We Know about Dietary Fiber Intake in Children and Health? The Effects of Fiber Intake on Constipation, Obesity, and Diabetes in Children. Adv Nutr 2012; 3: 47-53. doi: 10.3945/an.111.001362

29. Poole SA, Hart CN, Jelalian E, et al. Relationship between dietary energy density and dietary quality in overweight young children: a cross-sectional analysis. Pediatr Obes 2016; 11: 128-135. doi: 10.1111/ijpo.12034

30. Anderson JW, Baird P, Davis Jr RH, et al. Health benefits of dietary fiber. Nutr Rev 2009; 67: 188-205. doi: 10.1111/j.1753-4887.2009.00189.x

31. Emmett PM, Jones LR. Diet, growth, and obesity development throughout childhood in the Avon Longitudinal Study of Parents and Children. Nutr Rev 2015; 73 (Suppl 3): 175-206. doi: 10.1093/nutrit/ nuv054

32. Noel S, Ness A, Northstone K, et al. Associations between flavored milk consumption and changes in weight and body composition over time: differences among normal and overweight children. Eur J Clin Nutr 2013; 67: 295-300. doi: 10.1038/ejcn.2012.123

33. Dougkas A, Barr S, Reddy S, et al. A critical review of the role of milk and other dairy products in the development of obesity in children and adolescents. Nutr Res Rev 2019; 32: 106-127. doi: 10.1017/S0954422418000227

34. Manios Y, Moschonis G, Chrousos GP, et al. The double burden of obesity and iron deficiency on children and adolescents in Greece: the Healthy Growth Study. J Hum Nutr Diet 2013; 26: 470-478. doi: 10.1111/jhn. 12025

35. Aeberli I, Hurrell RF, Zimmermann MB. Overweight children have higher circulating hepcidin concentrations and lower iron status but have dietary iron intakes and bioavailability comparable with normal weight children. Int J Obes (Lond) 2009; 33: 1111-1117. doi: 10.1038/ijo.2009.146

36. Merkiel-Pawłowska S, Chalcarz W. Gender differences and typical nutrition concerns of the diets of preschool children - the results of the first stage of an intervention study. BMC Pediatrics 2017; 17 : 207. doi: 10.1186/s12887-017-0962-1

37. Florkiewicz A, Grzych-Tuleja E, Cieślik E, et al. Ocena pobrania z dietą wybranych składników mineralnych przez młodzież w wieku 13-15 lat w zależności od płci oraz miejsca zamieszkania. Zdr Publ Zarządz 2013; 11: 260-266.

38. Yang Q, Zhang Z, Kuklina EV, et al. Sodium intake and blood pressure among US children and adolescents. Pediatrics 2012; 130 : 611-619. doi: 10.1542/peds.2011-3870

39. Buendia JR, Bradlee ML, Daniels SR, et al. Longitudinal effects of dietary sodium and potassium on blood pressure in adolescent girls. JAMA Pediatr 2015; 169: 560-568. doi: 10.1001/jamapediatrics.2015.0411

40. WHO, Guideline: Sodium intake for adults and children, 2012, WHO Library Cataloguing-in-Publication https://www.who.int/nutrition/publications/guidelines/sodium_intake/en/ (Accesses on 24 October 2019). 
41. Gunanti IR, Marks GC, Al-Mamun A, et al. Low serum concentrations of carotenoids and vitamin $E$ are associated with high adiposity in Mexican-American children. J Nutr 2014; 144: 489-495. doi: 10.3945/jn.113.183137

42. Rusińska A, Płudowski P, Walczak M, et al. Vitamin D Supplementation Guidelines for General Population and Groups at Risk of Vitamin D Deficiency in Poland-Recommendations of the Polish Society of Pediatric Endocrinology and Diabetes and the Expert Panel With Participation of National Specialist Consultants and Representatives of Scientific Societies - 2018 Update. Front Endocrinol (Lausanne) 2018; 9: 246. doi: 10.3389/fendo.2018.00246

43. Chew WF, Leong PP, Yap SF, et al. Risk factors associated with abdominal obesity in suburban adolescents from a Malaysian district. Singapore Med J 2018; 59: 104-111. doi: 10.11622/smedj.2017013

44. Mihrshahi S, Drayton BA, Bauman AE, et al. Associations between childhood overweight, obesity, abdominal obesity and obesogenic behaviors and practices in Australian homes. BMC Public Health 2017; 18: 44. doi: 10.1186/s12889-017-4595-y
45. Nurul-Fadhilah A, Teo PS, Huybrechts, et al. Infrequent breakfast consumption is associated with higher body adiposity and abdominal obesity in Malaysian school-aged adolescents. PLoS One 2013; 8: e59297. doi: 10.1371/journal.pone.0059297

46. Monzani A, Ricotti R, Caputo M, et al. Systematic Review of the Association of Skipping Breakfast with Weight and Cardiometabolic Risk Factors in Children and Adolescents. What Should We Better Investigate in the Future? Nutrients 2019; 11: pii: E387. doi: 10.3390/nu11020387

47. Jennings A, Welch A, van Sluijs EMF, et al. Diet quality is independently associated with weight status in children aged 9-10 years. J Nutr 2011; 141: 453-459. doi: 10.3945/jn.110.131441

48. Muhammad AN, Varani J. The western-style diet, calcium deficiency and chronic disease. J Nutr Food Sci 2016; 6: 3. doi: 10.4172/21559600.1000496 